Website : http://agritek.unmermadiun.ac.id/index.php/agritek

\title{
Review: Peran Enzim dalam Meningkatkan Kualitas Kopi
}

\author{
Dany Ardiansyah ${ }^{1}$, Helen Tjota $^{2}$, Warsono El Kiyat ${ }^{3}$ \\ Departemen Teknologi Pangan dan Gizi, Fakultas Ilmu Hayati, Universitas Surya, Jl. MH. Thamrin Km 2.7, Banten 15117, Indonesia \\ *E-mail:warsono.el.kiyat@gmail.com
}

\begin{abstract}
Indonesia is the third largest coffee producing nation in the world after Brazil and Vietnam. The types and the characteristics of Indonesian coffee are different in each area but the main important factor of consumer acceptance depends on its bitterness level. Chlorogenic acid lactone is a compounds that play an important role as contributor to the coffee bitterness that are formed during the roasting process of coffee bean because of its precursor chlorogenic acid. Chlorogenic acid is commonly found in many plants. One of them can be found in coffee with high concentration. Chlorogenic acid lactone (bitter compound) can be hydrolyzed to chlorogenic acid (non-bitter compound) using hog liver esterase and chlorogenate esterase. This study aimed to analyze the use of these enzymes to decrease the level of bitterness in coffee. The results indicated that HLE and chlorogenate esterase effectively hydrolyzed chlorogenic acid lactones in coffee. Based on the sensory test, coffee extracts treated with enzymes were less bitter than the untreated coffee extracts. If it was associated with Indonesian local coffee then the method can be done with chlorogenate esterase that was in accordance with the legal guarantee of halal product.
\end{abstract}

Keywords - : chlorogenate esterase; chlorogenic acid; coffee; hog liver esterase; lakton chlorogenic acid.

\section{PENDAHULUAN}

Komoditas kopi lokal memiliki peran penting bagi sumber devisa negara dan penghasilan bagi petani kopi di Indonesia. Komoditas kopi dan jenisnya berbeda-beda pada setiap wilayah, sehingga karakteristik kopi bisa dijadikan sebagai identitas bangsa. Komoditas kopi pertama yang dibudidayakan di Indonesia adalah kopi arabika (Coffee arabica) yang berasal dari Afrika. Saat ini, sebagian kopi yang dibudidayakan di Indonesia adalah kopi robusta yaitu sekitar 90\% dan sisanya adalah kopi arabika. Meskipun pada awalnya kopi arabika lebih dulu dibudidayakan di Indonesia, atas beberapa hal jumlah pembudidayaan kopi arabika menurun dan tergantikan oleh kopi jenis robusta (Rahardjo, 2012). FAO menyebutkan bahwa Indonesia tercatat sebagai produsen kopi terbesar ketiga di dunia setelah Brazil dan Vietnam, dilanjutkan dengan Kolombia dan India (Food and Agriculture Organization, 2015). Produksi kopi meningkat dari tahun 2011 hingga tahun 2015 yaitu dari 22,22 ton menjadi 32 ton (Badan Pusat Statistik, 2017). Hal ini seiring dengan meningkatnya jumlah permintaan dan konsumsi kopi. Perkembangan konsumsi kopi di Indonesia pada tahun 2011 konsumsi kopi mencapai $1,366 \mathrm{~kg} / \mathrm{kapita} / \mathrm{tahun}$, mengalami penurunan di tahun 2012 dan kembali meningkat pada tahun 2013 yakni 1,371 kg/kapita/tahun (Kementerian Pertanian, 2016).

Karakteristik kopi mempengaruhi tingkat kesukaan bagi penyuka kopi, kopi dengan rasa pahit yang dominan banyak digemari namun banyak pula yang kurang menyukai kopi yang terlalu pahit. Oleh karena itu, tingkat kepahitan dalam kopi menjadi faktor utama dalam penentu penerimaan konsumen (Kraehenbuehl et al., 2017). Karakteristik masingmasing komoditas kopi bisa menjadi nilai tambah tersendiri. Biji kopi mengandung protein, minyak aromatis dan beberapa asam organik. Kafein secara alami terkandung pada biji kopi yang merupakan senyawa yang dapat menstimulasi sistem saraf pusat otot dan ginjal. Pemrosesan kopi melibatkan proses fermentasi dan pemanasan seperti pengeringan dan pemanggangan. Rasa dan karakteristik kopi dapat berubah disebabkan oleh proses pengolahan salah satunya pemanasan yang memungkinkan terjadinya perubahan komponenkomponen yang ada dalam biji kopi, bahkan adanya pembentukan senyawa baru yang mempengaruhi rasa dan karakteristik pada produk akhir pengolahan kopi.

Salah satu senyawa yang berkontribusi memberikan rasa pahit pada kopi adalah lakton asam klorogenat atau chlorogenic acid lactones. Senyawa lakton asam klorogenat ini terbentuk saat proses pemanggangan (roasting) oleh prekursornya yaitu asam klorogenat $\left(\mathrm{C}_{19} \mathrm{H}_{18} \mathrm{O}_{6}\right)$ (Clifford, 2000; Farah, De Paulis, Trugo, \& Martin, 2005). Asam klorogenat sendiri terkandung secara alami dalam biji kopi dengan kadar yang tinggi.

\section{KOPI}

\section{A. Pengertian dan Sejarah}

Kopi merupakan komoditas tanaman yang sering digunakan oleh banyak negara untuk proses ekspor sebagai sumber pendapatan negara. Indonesia merupakan negara tropis yang mudah untuk membudidayakan komoditas kopi. Umumnya, kopi yang sering dikonsumsi di dunia adalah kopi arabika dengan persentase $70 \%$, konsumsi kopi robusta $26 \%$, sedangkan sisa $4 \%$ adalah jenis kopi liberika dan ekselsa (Rahardjo, 2012). Di Indonesia, jenis kopi yang dapat dibudidayakan adalah kopi robusta $(90 \%)$ dan kopi arabika $(10 \%)$.

Pada awalnya, kopi arabika dibudidayakan di Pulau Jawa sehingga dikenal dengan kopi Jawa, namun akibat dari hama yang disebabkan oleh jamur Hemileia vastatrix, terjadi penyakit karat daun dan kematian tanaman kopi sehingga menimbulkan kerugian besar. Oleh karena itu, dikembangkan kopi robusta yang lebih tahan terhadap hama, sedangkan kopi arabika dibudidayakan di dataran tinggi mencapai lebih dari 1000 mdpl untuk mencegah penyerangan hama $H$. vastatrix. Hal ini menyebabkan kopi robusta lebih banyak dibudidayakan, dikembangkan, dan dikonsumsi oleh masyarakat Indonesia. 


\section{B. Jenis Spesialitas Kopi}

Website : http://agritek.unmermadiun.ac.id/index.php/agritek

Spesialitas kopi merupakan kopi yang dibudidayakan secara spesial yang biasanya menjadi ciri khas dari suatu daerah tempat budidaya kopi tersebut. Setiap daerah di Indonesia umumnya bersaing untuk menciptakan kopi yang menjadi ciri khas dari daerah tersebut, beberapa spesialitas kopi (Yuliandri, 2015) adalah sebagai berikut:

1) Kopi Toraja: merupakan kopi khas dari daerah Tana Toraja, Sulawesi Selatan. Ciri khas yang terdapat pada kopi toraja ada pada aroma berbau tanah dan tingkat keasamannya yang tinggi. Biji kopi toraja juga berbeda daripada biji kopi lain, bentuknya lebih kecil, licin, dan mengkilap. Kopi toraja terdapat dalam dua jenis yaitu kopi toraja arabika dan kopi toraja robusta.

2) Kopi Jawa: adalah kopi khas Pegunungan Ijen, Bodowoso, Jawa Timur. Keunikan yang dimiliki oleh kopi Jawa adalah adanya aroma rempah tipis yang dihasilkan pada saat diminum, walaupun rasa dan aroma kopinya tidak sekuat kopi lainnya namun tidak banyak kopi yang dapat menghasilkan bau rempah-rempah.

3) Kopi Gayo: merupakan kopi arabika khas Takengon, Banda Aceh. Ciri khas dari kopi gayo ini adalah rasa pahit dan tingkat keasamannya lebih tinggi dibandingkan kopi lainnya sehingga dari segi rasa dan aroma kopi gayo ini sangat kuat cita rasanya. walaupun pahit tapi terdapat rasa gurih ketika meminum kopi gayo.

4) Kopi Bali Kintamani: keunikan dari kopi yang berasal dari Kintamani, Bangli, Bali ini adalah cita rasanya yang mengandung aroma buah-buahan asam dan segar, didapatnya aroma buah-buahan karena kopi Kintamani ditanam bersamaan dengan komoditas buah dan sayur sebagai ciri khasnya.

5) Kopi luwak: merupakan buah kopi yang dimakan oleh musang luwak yang kemudian mengalami proses fermentasi dalam perut musang luwak, buah yang dimakan beserta bijinya di mana feses biji kopi dalam keadaan utuh dibersihkan dan diolah sama seperti pengolahan biji kopi lain (Ikhwan, 2013).

Spesialitas kopi umumnya merupakan kopi organik yang secara langsung ditanam oleh petani secara berkelanjutan. Oleh karena itu, jenis kopi tersebut memiliki harga yang umumnya lebih tinggi dibandingkan kopi biasa.

\section{KARAKTERISTIK KIMIA KOPI}

Asam klorogenat merupakan senyawa fenolik yang umumnya ditemui pada biji kopi ataupun pada kopi dengan konsentrasi yang tinggi mencapai 7-10\% (Coffee Intelegence, 2015). Asam klorogenat terbentuk dari ester asam transkinamat, seperti asam kafeat, dengan asam quinat dan berperan penting pada pengaruh rasa dan aroma dari biji kopi ataupun kopi yang dihasilkan. Adapun kandungan kimia kopi disajikan pada Tabel 1 .
Tabel 1.

Kandungan kimia pada kopi

\begin{tabular}{lll}
\hline \multicolumn{1}{c}{ Kandungan } & \multicolumn{2}{c}{ Konsentrasi (g/100g) } \\
\cline { 2 - 3 } Kumia & Regular & Bold \\
\hline Sukrosa & 4,2 & 1,6 \\
Kafein & $1,1-1,3$ & $2,4-2,5$ \\
Asam & $1,9-2,5$ & $3,3-3,8$ \\
klorogenat & & \\
Protein & $6,5-10$ & $7,5-10$ \\
Polisakarida & $31-33$ & 37 \\
\hline
\end{tabular}

Sumber: (Farhaty \& Muchtaridi, 2016)

Studi terdahulu menunjukkan bahwa pengaruh asam klorogenat pada produk akhir dari kopi sangat penting karena memengaruhi tingkat keasaman dan kepahitan dari kopi tersebut (Ayelign \& Sabally, 2013). Penelitian lain menyebutkan bahwa pengolahan kopi dengan cara dipanggang dapat meningkatkan kadar lakton asam klorogenat yang dapat dibentuk akibat tingginya prekursor yang terdapat pada biji kopi yaitu asam klorogenat (Farah et al., 2005). Pengolahan kopi yang dilakukan secara dipanaskan atau dipanggang menyebabkan terjadi reaksi maillard yang dapat meningkatkan tingkat kepahitan dari kopi (Farah, De Paulis, Moreira, Trugo, \& Martin, 2006).<smiles>O=C(/C=C/c1ccc(O)c(O)c1)O[C@H]1C[C@@](O)(C(=O)O)C[C@H](O)[C@H]1O</smiles>

Gambar 1. Struktur kimia asam klorogenat (Coffee Intelegence, 2015)

\section{IV.ENZIM-ENZIM YANG BERPERAN PADA KUALITAS KOPI}

\section{A. Enzim Klorogenat Esterase}

Enzim klorogenat esterase (EC 3.1.1.42) merupakan enzim yang diperoleh dari Aspergillus niger yang dapat berfungsi untuk menghidrolisis senyawa ester dari asam hidroksinamat. Enzim ini mampu bekerja optimum pada $\mathrm{pH}$ 7,5 dan suhu $37^{\circ} \mathrm{C}$, tetapi tetap aktif pada $\mathrm{pH} 3,5-9,5$ yang menunjukkan bahwa enzim dapat tetap bekerja dengan baik pada jangkauan pH yang luas (Nieter et al., 2015).

Enzim klorogenat esterase memiliki nama lain yaitu enzim klorogenat hidrolase yang berfungsi sama dalam menghirolisis asam klorogenat. Selain Aspergillus niger dapat pula digunakan Lactobacillus johnsonii dipercaya dapat melakukan metabolisme terhadap asam klorogenat menjadi asam kafeat dan asam ferulik (Bel-Rhlid, Thapa, Kraehenbuehl, Hansen, \& Fischer, 2013).

\section{B. Enzim Hog Liver Esterase}

Enzim hog liver esterase (HLE) merupakan enzim yang didapatkan dari hasil ekstraksi pada hati babi yang umumnya digunakan sebagai biokatalis pada sintesis organik. Kinerja enzim ini bekerja secara spesifik kepada proses hidrolisis senyawa ester gugus karboksil (Hasenpusch, Möller, Bornscheuer, \& Langel, 2012). Umumnya, enzim HLE bekerja optimum pada $\mathrm{pH}$ 7-8 dan apabila berada pada kondisi 
Website : http://agritek.unmermadiun.ac.id/index.php/agritek

$\mathrm{pH}$ dibawah 4 maka enzim dapat terdenaturasi (Barker \& Jencks, 1969). HLE umumnya dikenal dengan nama pig liver esterase (PLE) yang berguna dalam proses sintesis organik, terbukti dengan PLE dapat menjadi katalis alkoholisasi dalam studi hidrasi yang rendah (Lopes, Fraga, Fleuri, \& Macedo, 2011).

\section{MEKANISME KERJA ENZIM KLOROGENAT ESTERASE (KE) DAN HOG LIVER ESTERASE (HLE)}

Pada penelitian yang dilakukan oleh Kraehenbuehl et al. menggunakan beberapa ekstraksi enzim klorogenat esterase yang berasal dari esterase hati babi yang dibawa oleh eupergit $\mathrm{C}$ agar enzim terimobilasi dan ada pula klorogenat esterase yang berasal dari Aspergillus japonicus. Selain kedua enzim tersebut, terdapat pula enzim tannase, palatase, dan lipase yang dapat diujikan terlebih dahulu kinerjanya pada sampel kopi. Hal ini dilakukan untuk mengetahui enzim yang dapat bekerja selektif terhadap subsrat yang terdapat pada kopi. Sampel kopi yang digunakan merupakan kopi $100 \%$ robusta yang berasal dari Tanzania dengan tingkat pemanggangan sedang. Pada percobaan pengujian selektif enzim yang digunakan, sampel yang digunakan tidak menggunakan sampel kopi melainkan campuran 3-caffeoylquinic acid lactone, 4-caffeoylquinic acid lactone, dan 4-feruloilquinat acid lactone yang dipreparasi melalui sintesis organik sehingga dapat terlihat kinerjanya secara spesifik (Kraehenbuehl et al., 2017).

Lakton asam klorogenat terbentuk selama proses seiring dengan hilangnya molekul air dari bagian asam quinat dan pembentukan ikatan ester intramolekul. Lakton asam klorogenat diekspresikan dalam sistem model yang terdiri dari campuran 3-caffeoylquinic acid lactones, 4-caffeoylquinic acid lactones, dan 4-feruloilquinat acid lactones yang dipreparasi melalui sintesis organik. Campuran lakton tersebut diinkubasi dengan enzim yang berbeda selama 2 dan 24 jam. Hidrolisis lakton tersebut dilakukan sebagai tahap skrining enzim yang akan diaplikasikan pada ekstrak kopi (Kraehenbuehl et al., 2017).

Hasil penelitian menunjukkan bahwa 3-CQAL (3caffeoylquinic acid lactones) dapat terdegradasi oleh enzim tannase, enzim HLE (Hog Liver Esterase) terimobilasi, enzim palatase dan enzim klorogenat esterase (KE). Sementara, Enzim lipase dari mikroorganisme Candida rugosa, Candida cylindracea, dan Candida antarctica tidak mampu mendegradasi lakton. Mekanisme penguraian atau hidrolisis dapat dilihat pada Gambar 2. Hidrolisis yang dilakukan oleh enzim klorogenat esterase terjadi melalui dua tahap yaitu dengan mengubah lakton asam klorogenat menjadi asam klorogenat kemudian dipecah menjadi masing-masing senyawa asam seperti asam kafeat atau asam ferulat, sedangkan mekanisme enzim HLE yakni dengan menghidrolisis lakton asam klorogenat secara langsung ke dalam bentuk asam klorogenat. Hasil ini menunjukkan bahwa asam klorogenat dan lakton yang sesuai dapat dihidrolisis oleh enzim esterase, tetapi tidak oleh enzim lipase. Enzim esterase dan lipase keduanya merupakan enzim hidrolase ikatan ester. Namun, aktivitas enzim esterase lebih tinggi terhadap keadaan substrat yang terlarut dalam air (Fojan, Jonson, Petersen, \& Petersen, 2000). Enzim lipase lebih aktif pada substrat yang tidak larut air seperti trigliserida yang terkomposisi dari asam lemak rantai panjang, sedangkan esterase lebih aktif menghidrolisis ester sederhana dan hanya trigliserida yang terkomposisi dari asam lemak rantai pendek (Lopes et al., 2011). Kedua enzim tersebut tetap stabil dalam pelarut organik. Namun, sifat ini lebih dimiliki oleh lipase.

Hidrolisis 3-CQAL, 4-CQAL dan 4-FQAL menghasilkan peningkatan konsentrasi caffeic acid (CA) dan ferulic acid (FA) yang diukur menggunakan HPLC. Gambar 2 menunjukkan transformasi bentuk senyawa lakton asam klorogenat menjadi asam klorogenat dengan enzim klorogenat esterase pada jalur A1 + A2 dan enzim HLE pada jalur B1. Dengan demikian, enzim yang dapat digunakan dalam pengujian pada sampel ekstrak kopi adalah enzim HLE, KE, palatase, dan tannase. Namun, karena hasil penambahan enzim palatase dan tannase tidak mengalami perubahan signifikan maka pembahasan akan berfokus pada enzim HLE dan KE.

Perbedaan proses hidrolisis yang terjadi pada lakton asam klorogenat oleh enzim HLE dan KE terlihat pada reaksinya. Pada enzim HLE disebut sebagai enzim yang selektif dikarenakan reaksinya yang langsung merubah asam lakton klorogenat menjadi asam klorogenat. Seperti yang dijelaskan dalam Tabel 2, jumlah CQA dan FQA yang terhidrolisis sangat kecil. Jumlah CQA dan FQA yang terhidrolisis oleh enzim hog liver esterase mengalami peningkatan seiring dengan konsentrasi enzim yang bertambah dan lama inkubasi yang dilakukan. Hal ini menunjukan bahwa enzim HLE bekerja secara spesifik di mana yang dihidrolisis oleh enzim HLE hanya asam klorogenat dengan laktonnya saja. Seperti yang dapat dilihat pada tabel bahwa jumlah CQAL dan FQAL yang dihidrolisis jauh lebih tinggi dibanding CQA dan FQA.

Berbeda dengan proses hidrolosis enzim KE, asam lakton klorogenat diubah menjadi asam kafeat dan asam ferulat yang baru akan terpecah kembali menjadi asam klorogenat. 


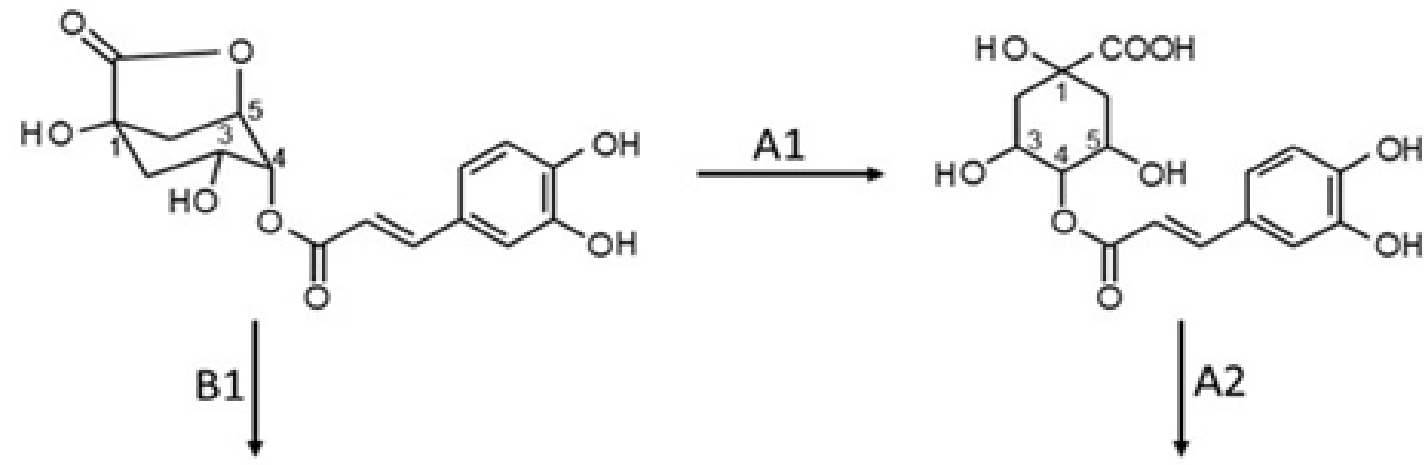<smiles>CC(C)C(=O)OC1CC(O)(C(=O)O)CC(O)C1O</smiles>

Gambar 2. Proses hidrolisis lakton asam klorogenat oleh enzim HLE dan KE (Kraehenbuehl et al., 2017)

Enzim KE efektif dalam menghidrolisis senyawa lakton asam klorogenat dan asam klorogenat. Enzim KE tidak bekerja secara selektif, sehingga komponen positif yang diinginkan ikut terhidrolisis oleh enzim chlorogenate esterase. Konsentrasi penggunaan enzim KE yang sangat rendah sekalipun dapat menghidrolisis seratus persen senyawa CQAL dalam waktu yang singkat. Seperti yang disajikan pada Tabel 2, jumlah CQA yang terhidrolisis menggunakan enzim $\mathrm{KE}$ lebih banyak dibanding jumlah FQAL yang dihidrolisis oleh enzim KE. Hal ini dapat dikatakan bahwa penggunaan enzim KE dapat bekerja secara efektif pada senyawa asam kafeat dibandingkan pada asam ferulat.

Berdasarkan mekanismenya, enzim KE menghidrolisis secara non selektif sehingga pada akhir reaksi konsentrasi senyawa CQA dan FQA mengalami peningkatan yang dikhawatirkan mengalami pembentukan kembali menjadi lakton asam klorogenat yang berkontribusi memberikan rasa pahit pada kopi.

\section{HIDROLISIS ENZIMATIS LAKTON ASAM KLOROGENAT PADA EKSTRAK KOPI}

\section{A. Hidrolisis dengan Enzim HLE (Hog Liver Esterase) Terimobilisasi}

Enzim hog liver esterase atau esterase dari hati babi memiliki aktivitas konversi katalisis model enantioselektif komponen ester menjadi asam karboksilat. Enzim ini sangat berguna untuk proses sintesis organik. Isoenzim dari HLE atau PLE (Pig Liver Esterase) memiliki dua aktivitas yaitu sebagai esterase dan amidase dengan dejarat selektivitas yang

Tabel 2.

Persentase hidrolisis CQALs, CQAs, FQALs, dan FQA oleh enzim HLE dan CE

\begin{tabular}{|c|c|c|c|c|c|}
\hline & & CQALs & CQAs & FQALs & FQA \\
\hline \multicolumn{6}{|l|}{ Hog Liver Esterase } \\
\hline \multirow[t]{2}{*}{$0,2 \mathrm{U} / \mathrm{mg}$} & 2 jam & $82 \%$ & $4 \%$ & $63 \%$ & $2 \%$ \\
\hline & 4 jam & $90 \%$ & $5 \%$ & $72 \%$ & $3 \%$ \\
\hline \multirow[t]{2}{*}{$0,5 \mathrm{U} / \mathrm{mg}$} & 2 jam & $94 \%$ & $5 \%$ & $70 \%$ & $3 \%$ \\
\hline & 4 jam & $98 \%$ & $6 \%$ & $75 \%$ & $4 \%$ \\
\hline \multicolumn{6}{|l|}{ Klorogenat Esterase } \\
\hline \multirow[t]{3}{*}{$0,01 \mathrm{U} / \mathrm{mg}$} & 0,5 jam & $100 \%$ & $72 \%$ & $62 \%$ & $25 \%$ \\
\hline & 1 jam & $100 \%$ & $80 \%$ & $70 \%$ & $30 \%$ \\
\hline & 2 jam & $100 \%$ & $85 \%$ & $83 \%$ & $38 \%$ \\
\hline
\end{tabular}

Sumber: Kaerhenbuehl et al. (2017) 
Website : http://agritek.unmermadiun.ac.id/index.php/agritek

berbeda untuk substrat dan enantiomer (Hasenpusch et al., 2012). Mekanisme enantioselektif enzim HLE untuk hidrolisis ester dibagi menjadi beberapa tahap. Pada tahap pertama molekul substrat mengakses pusat aktif enzim dari larutan. Selanjutnya molekul harus sesuai dengan kantong pengikat enzim dalam posisi yang memungkinkan interaksi dengan katalitik triad. Model enantioselektivitas ini dimaksudkan hanya satu dari dua enantiomer yang sesuai dengan geometri rigid dari sisi aktif dengan prinsip reaksi key and lock. Pembelahan ester di dalam sisi aktif dimulai dengan pembentukan ikatan antara $\mathrm{O} \gamma$ serin dalam triase katalitik dan atom karbon ester dari substrat. Dua langkah penting tersebut memberikan pemecahan ikatan di dalam ester dan serin, membebaskan alkohol dan asamnya masing-masing. Pelepasan produk yang lambat dari situs aktif akan menghalangi siklus reaksi enzimatik berikutnya.

Enzim HLE direaksikan pada ekstrak kopi yaitu pada $40^{\circ} \mathrm{C}$ konsentrasi substrat $0,2 \mathrm{U} / \mathrm{mg}$. Ekstrak kopi yang digunakan terdiri dari tiga konsentrasi yang berbeda yaitu 3\%, 5\%, dan $10 \%$. Hasil pengujian kinetika enzim HLE terhadap ekstrak kopi yakni $80 \%$ lakton asam kafeoilquinat terhidrolisis pada kopi dengan konsentrasi 3\% selama 2 jam dan terhidrolisis sempurna setelah mencapai 8 jam. Hidrolisis lakton asam kafeoilquinat (CQA) ini seiring dengan meningkatnya konsentrasi asam kafeat. Pada kopi konsentrasi tinggi yaitu $10 \%$ hidrolisis berlangsung lama yang disebabkan komponen lain pada kopi bisa berperan sebagai inhibitor enzim yang digunakan. Hidrolisis pada lakton asam feruloilquinat oleh HLE lebih lambat dibanding pada lakton asam kafeoilquinat. Demikian dapat dikatakan bahwa rantai samping ester memberikan dampak pada laju reaksi.

\section{B. Hidrolisis dengan Enzim KE (Klorogenat Esterase)}

Berdasarkan hasil pengujian yang dapat dilihat pada Tabel 1, ekstrak kopi dengan konsentrasi 3\% yang diinkubasi dengan klorogenat esterase pada $40^{\circ} \mathrm{C}$ dengan konsentrasi enzim 0,01 U/mg, seluruh CQAL dan lebih dari $80 \%$ CQA terhidrolisis setelah reaksi berlangsung selama 2 jam. Enzim asam klorogenat esterase (EC 3.1.1.42) biasanya diperoleh dari mikroorganisme Aspergillus sp. Karakteristik enzim ini memiliki kemampuan optimal pada suhu $37^{\circ} \mathrm{C}, \mathrm{pH} 3$ hingga 8,5 , pengaruh penambahan pelarut heksana dapat meningkatkan aktivitas relatif klorogenat esterase, dan dapat terhambat karena ion-ion logam seperti $\mathrm{Mn}^{+2}$ dan $\mathrm{Hg}^{+2}$ (Nieter et al., 2015). Reaksi yang terjadi adalah asam klorogenat dengan air terhidrolisis dengan bantuan enzim klorogenat esterase menghasilkan asam kafeat dan quinat Sedangkan enzim feruloyl esterase (EC 3.1.1.73) masih termasuk dalam kelompok karboksilik ester hidrolase seperti klorogenat esterase. Seluruh asam klorogenat (CQA, FQA) dan lakton nya yang sesuai (CQAL, FQAL) terhidrolisis sempurna pada saat konsentrasi enzim dinaikkan yaitu $10 \mathrm{U} / \mathrm{mg}$ dan selama 4 jam reaksi. Laju reaksi hidrolisis pada FQAL dan FQA lebih lambat dibanding CQAL dan CQA namun FQAL lebih cepat terhidrolisis dibanding FQA karena adanya ikatan lakton yang dapat dihidrolisis dengan mudah. Perlakuan enzim klorogenat esterase pada ekstrak kopi ini menghasilkan asam kafeat, ferulat dan quinat yang tinggi.

\section{VII. \\ PERAN ENZIM DALAM MEMPERBAIKI KARAKTERISTIK SENSORI KOPI}

Pengujian sensori yang dilakukan oleh Kraehenbuehl et al. menggunakan 12 panelis terlatih dengan dua perlakuan yang dibekali penutup hidung dan tanpa penutup hidung, sehingga pengujian sensori dapat dibandingkan. Sampel kopi yang disajikan adalah kopi dengan penambahan HLE yang memiliki konsentasi $0,2 \mathrm{U} / \mathrm{mg}$ dan sudah dihidrolisis selama 4 jam dan kopi dengan penambahan KE yang berkonsentrasi 10 U/mg yang dihidrolisis selama 30 menit. Hasil pengujian sampel yang dilakukan terdapat pada Gambar 3 dan 4. Gambar 3 menunjukkan bahwa hasil penilaian tingkat kepahitan kopi mengalami penurunan rasa pahit yang signifikan untuk sampel kopi dengan penambahan HLE sedangkan penambahan KE mengalami penurunan, tetapi tidak signifikan, sedangkan pada Gambar 4 menunjukkan bahwa atribut rasa pahit yang diuji menghasilkan nilai yang lebih tinggi untuk sampel kopi dengan penambahan HLE dan KE dibandingkan perlakuan Gambar 3 yang dipengaruhi oleh indera penciuman. Pengaruh enzim HLE dan KE untuk mereduksi rasa pahit juga bergantung pada jenis dari kopi tersebut, selain itu juga faktor lamanya pemanggangan setiap produsen kopi juga berbeda sehingga dapat menghasilkan rasa pahit yang berbeda (Kraehenbuehl et al., 2017).

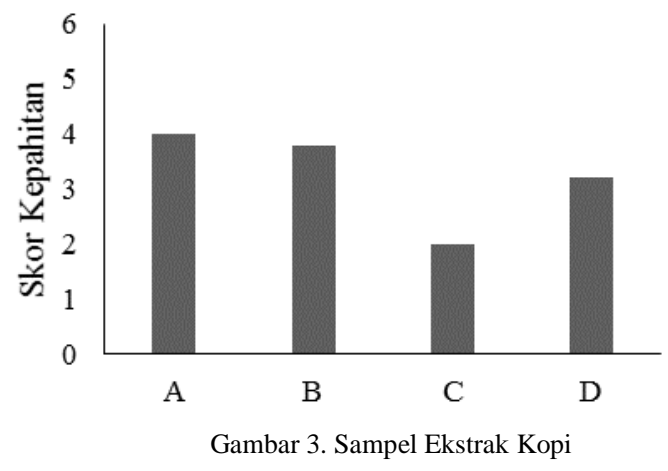

Gambar 3. Skor kepahitan ekstrak kopi dengan penambahan enzim HLE (C), enzim KE (D), enzim HLE dan KE (A), dan tanpa enzim HLE dan KE (B) (Kraehenbuehl et al., 2017).

Enzim yang digunakan yakni enzim klorogenat esterase dan esterase dari hati babi (Hog Liver Esterase) diketahui memiliki efektivitas yang baik bagi penurunan lakton asam klorogenat yang berkontribusi sebagai senyawa pemberi rasa pahit pada kopi. Hidrolisis lakton asam klorogenat secara selektif yaitu menggunakan enzim HLE atau Hog Liver Esterase. Hidrolisis secara selektif ini dinilai lebih baik dibanding non-selektif karena tidak mempengaruhi atribut positif pada kopi yang terbentuk selama proses pemanggangan (roasting) biji kopi. Menurut Undang-undang Nomor 33 Tahun 2014 tentang Jaminan Produk Halal pasal 18 ayat 2 menyebutkan bahwa babi merupakan hewan yang diharamkan (Presiden RI, 2014). Berdasarkan bunyi pasal tersebut, penggunaan enzim HLE di Indonesia tidak dapat diaplikasikan, hal ini diperkuat oleh bunyi pasal 20 ayat 2 yang mengharamkan bahan dan produk jika proses pertumbuhan dan/atau pembuatannya tercampur, terkandung, dan/atau terkontaminasi dengan bahan yang diharamkan. 
Website : http://agritek.unmermadiun.ac.id/index.php/agritek

\section{UCAPAN TERIMAKASIH}

Bitter

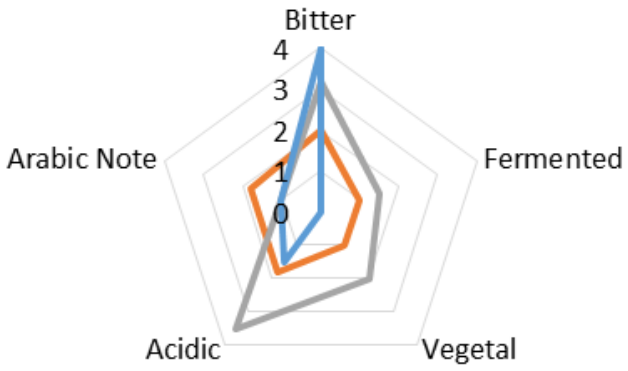

Gambar 4. Karakteristik sensori ekstrak kopi dengan penambahan enzim HLE (orange), enzim KE (abu-abu), dan tanpa enzim HLE dan KE (biru) (Kraehenbuehl et al., 2017).

Penggunaan enzim klorogenat esterase lebih dipilih untuk menurunkan tingkat kepahitan pada kopi Nusantara. Kopi lokal dalam hal ini adalah kopi jenis robusta yang diketahui asam klorogenatnya lebih tinggi daripada kopi jenis arabika. Kopi jenis arabika lebih banyak menguasai pasar dibanding kopi jenis robusta karena cita rasa yang tidak terlalu pahit dibanding jenis kopi robusta (JPW Coffee, 2013). Salah satu kopi jenis robusta di Indonesia adalah kopi luwak. Kopi luwak sendiri merupakan buah kopi yang dimakan oleh musang luwak yang kemudian mengalami proses fermentasi dalam perut musang luwak, buah yang dimakan beserta bijinya di mana feses biji kopi dalam keadaan utuh dibersihkan dan diolah sama seperti pengolahan biji kopi lainnya (Ikhwan, 2013). Aplikasi enzim klorogenat esterase bisa diterapkan lebih luas pada kopi lokal jenis robusta maupun jenis lainnya yang dinilai masih memiliki tingkat kepahitan yang tinggi untuk memperluas pasar dan meningkatkan kesukaan konsumen kopi Indonesia.

\section{KESIMPULAN}

Berdasarkan hasil kajian ini, disimpulkan bahwa enzim dapat menurunkan tingkat kepahitan kopi berdasarkan jumlah lakton asam klorogenat dan asam klorogenat yang dihasilkan. Enzim yang berperan pada penurunan tingkat kepahitan kopi adalah hog liver esterase (HLE) dan klorogenat esterase (KE). Senyawa lakton asam klorogenat yang menimbulkan rasa pahit akan dihidrolisis menjadi asam klorogenat sehingga tingkat kepahitannya menurun. Kondisi optimum enzim HLE adalah pada konsentrasi $0,2 \mathrm{U} / \mathrm{mg}$ dan direaksikan selama 4 jam, sedangkan untuk enzim KE adalah konsentrasi $10 \mathrm{U} / \mathrm{mg}$ selama 30 menit hidrolisis. Hasil penurunan kadar lakton asam klorogenat dikuatkan dengan pengujian sensori yang menunjukkan bahwa terdapat penurunan tingkat kepahitan yang signifikan pada sampel kopi dengan penambahan enzim HLE. Metode penurunan tingkat kepahitan ini dapat digunakan pada kopi lokal Indonesia, namun karena terkait Undang-undang Jaminan Produk Halal maka lebih baik menggunakan enzim klorogenat esterase untuk menurunkan tingkat kepahitan pada kopi lokal Indonesia.
Ucapan terima kasih diberikan kepada Lembaga Penelitian dan Pengabdian Masyarakat (LPPM) Universitas Surya atas bimbingan dan konsultasinya selama penyusunan naskah ini.

\section{DAFTAR PUSTAKA}

Ayelign, A., \& Sabally, K. (2013). Determination of Chlorogenic Acids (CGA) in Coffee Beans using HPLC. American Journal of Research Communication, 1(2), 78-91.

Badan Pusat Statistik. (2017). Produksi Perkebunan Besar menurut Jeni Tanaman, Indonesia (Ton), 1995-2017. Jakarta. Retrieved from https://www.bps.go.id/dynamictable/2018/06/08/1474/produksiperkebunan-besar-menurut-jenis-tanaman-indonesia-ton-1995-2017-.htm

Barker, D. L., \& Jencks, W. P. (1969). Pig liver esterase. Physical properties. Biochemistry, 8(10), 3879-3889. https://doi.org/10.1021/bi00838a001

Bel-Rhlid, R., Thapa, D., Kraehenbuehl, K., Hansen, C. E., \& Fischer, L. (2013). Biotransformation of caffeoyl quinic acids from green coffee extracts by Lactobacillus johnsonii NCC 533. AMB Express, 3(1), 1 https://doi.org/10.1186/2191-0855-3-28

Clifford, M. N. (2000). Chlorogenic acids and other cinnamates - nature occurrence, dietary burden, absorption and metabolism. Journal of the Science of Food and Agriculture, 1043(October 1999), 1033-1043.

Coffee Intelegence. (2015). Chlorogenic Acid. Retrieved August 1, 2018 , from https://www.coffeechemistry.com/chemistry/acids/chlorogenic-acid

Farah, A., De Paulis, T., Moreira, D. P., Trugo, L. C., \& Martin, P. R. (2006) Chlorogenic Acids and Lactones in Regular and Water-Decaffeinated Arabica Coffees. Journal of Agricultural and Food Chemistry, 54(2), 374-381. https://doi.org/10.1021/jf0518305

Farah, A., De Paulis, T., Trugo, L. C., \& Martin, P. R. (2005). Effect of Roasting on the Formation of Chlorogenic Acid Lactones in Coffee. Journal of Agricultural and Food Chemistry, 53(5), 1505-1513. https://doi.org/10.1021/jf048701t

Farhaty, N., \& Muchtaridi, M. (2016). Tinjauan Kimia dan Aspek Farmakologi Senyawa Asam Klorogenat pada Biji Kopi. Jurnal Farmaka, 14(1), 214-227. https://doi.org/https://doi.org/10.24198/jf.v14i1.10769

Fojan, P., Jonson, P. H., Petersen, M. T. N., \& Petersen, S. B. (2000). What distinguishes an esterase from a lipase : A novel structural approach. Biochimie, 82(11), 1033-1041. https://doi.org/https://doi.org/10.1016/S0300-9084(00)01188-3

Food and Agriculture Organization. (2015). FAO Statistical Pocketbook. Rome: Food and Agriculture Organization, United Nations.

Hasenpusch, D., Möller, D., Bornscheuer, U. T., \& Langel, W. (2012) Substrate-Enzyme Interaction in Pig Liver Esterase. Greifswald. Retrieved from https://arxiv.org/abs/1204.6186

Ikhwan, B. F. (2013). Pesona Kopi Luwak, 1-20. Retrieved from http://djpen.kemendag.go.id/app_frontend/admin/docs/publication/15513 90367153.pdf

JPW Coffee. (2013). Beda Kopi Luwak Arabika Dan Robusta Dari Segi Rasa Retrieved October 1, 2018, from http://www.jpwcoffee.com/beda-kopiluwak-arabika-dan-robusta-dari-segi-rasa

Kementerian Pertanian. (2016). Outlook Kopi: Komoditas Pertanian Subsektor Perkebunan. (L. Nuryati \& A. Yasin, Eds.). Jakarta: Pusat Data dan Sistem Informasi Pertanian Sekretariat Jenderal - Kementerian Pertanian.

Kraehenbuehl, K., Page-zoerkler, N., Mauroux, O., Gartenmann, K., Blank, I., \& Bel-rhlid, R. (2017). Selective enzymatic hydrolysis of chlorogenic acid lactones in a model system and in a coffee extract. Application to reduction of coffee bitterness. Food Chemistry, 218(1), 9-14. https://doi.org/10.1016/j.foodchem.2016.09.055

Lopes, D. B., Fraga, L. P., Fleuri, L. F., \& Macedo, G. A. (2011). Lipase and esterase - to what extent can this classification be applied accurately ? Food Science and Technology (Campinas), 31(3), 608-613. https://doi.org/http://dx.doi.org/10.1590/S0101-20612011000300009

Nieter, A., Haase-aschoff, P., Kelle, S., Linke, D., Krings, U., Popper, L., \& Berger, G. (2015). A Chlorogenic Acid Esterase with a Unique Substrate Specificity from Ustilago maydis. Applied and Environmental Microbiology, 81(5), 1679-1688. https://doi.org/10.1128/AEM.02911-14

Presiden RI. (2014). Undang-Undang Republik Indonesia Nomor 33 Tahun 2014 tentang Jaminan Produk Halal. Jakarta, Indonesia.

Rahardjo, P. (2012). Kopi: Panduan Budidaya dan Pengolahan Kopi Arabika dan Robusta. (Q. Trias, Ed.). Depok: Penebar Swadaya.

Yuliandri, M. T. (2015). Jenis-Jenis Kopi Nusantara. Retrieved August 1, 2018, from https://majalah.ottencoffee.co.id/jenis-jenis-kopi-nusantara/ 